DOI: 10.2478/tperj-2013-0012

\title{
Diagnostic Methods in Piriformis Syndrome
}

\section{Mariana BÂRZU1}

\begin{abstract}
An uncomon cause of sciatica is piriformis syndrome, that involves deep buttock pain reffered to the leg. Piriformis syndrome is usually discribed as a neuromuscular disorder caused by compression or irritation of the sciatic nerve by the piriformis muscle. There are a lot of means to diagnose Piriformis syndrome, and to distinguish it from other pain inducing conditions. Unfortunatelly not every practitioner has the opportunity to use special means, and not every patient has the financial support to beneficiate of the same special means, represented by Computed tomography (CT), Magnetic resonance imaging (MRI), Electromyography (EMG) and Neurography. For this reason, the present paper gathered the most popular functional tests used in the practice to diagnose the piriformis syndrome
\end{abstract}

Key words: piriformis muscle, sciatic nerve, functional test, orthopedic test

\section{Rezumat}

O cauză mai puțin obișnuită a sciaticii este sindromul piriform, care se manifestă prin durere în profunzimea regiunii fesiere, durere ce iradiază de-a lungul membrului inferior. În mod obișnuit, sindromul piriform este descris drept o tulburare morfo-funcțională neuromusculară datorată comprimării sau iritării nervului sciatic de către mușchiul piriform. Există o serie întreagă de metode și mijloace de diagnosticare a sindromului piriform și a putea face distincția intre acesta și durerile de altă etiologie, din aceiași regiune anatomică. Din păcate nu toți terapeuții au ocazia de a utiliza mijloace speciale de diagnostic și nici toți pacienții nu beneficiază de mijloacele financiare necesare pentru a accede la aceleași mijloace speciale de diagnostic, reprezentate de tomografia computerizată (CT), rezonanța magnetică nucleară(MRI), electromiografia (EMG) și neurografia. Din acest motiv, articolul de față a adunat din literatura de specialitate, testele funcționale cel mai frecvent utilizate în practică pentru diagnosticarea sindromului piriform.

Cuvinte cheie: mușchi piriform, sindrom piriform, test funcțional, test ortopedic

${ }^{1}$ Lecturer PhD, West University of Timișoara, Faculty of Physical Education and Sports, e-mail: mariana.barzu@e-uvt.ro 
Timisoara Physical Education and Rehabilitation Journal

Piriformis syndrome is one of the causes of sciatica, involving deep buttock pain associated or not with radiation to the leg, limping, occasional numbness and paraesthesias without definitive weakness. It is usually discribed as a neuromuscular disorder caused by compression or irritation of the sciatic nerve by the piriformis muscle [1].

Piriformis muscle is one of the most profound muscles of the buttock, originating from the anterior surface of the sacrum, at the level of vertebrae S2S4, near the sacroiliac joint capsule, pases through the greater sciatic notch and attaches to the superior medial aspect of the greater trochanter via a round tendon. Boyajian-O'Neil [2] shows that in as much as $96 \%$ of the population, the sciatic nerve leaves the pelvis through the foramen infrapiriforme, deep along the inferior surface of the piriformis muscle. The same author approximates that $22 \%$ of the population presents some anatomical variations of the region, concerning the piriformis muscle and / or the sciatic nerve. Actually, medical literature reports six main variations witch may cause in some cases, the origin of piriformis syndrome (Figure 1).

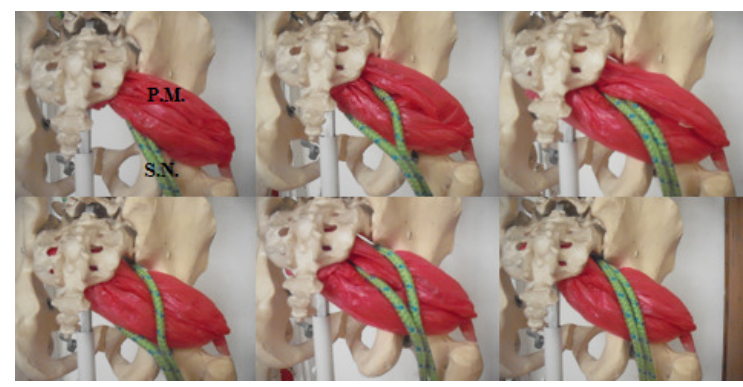

Figure 1. Anatomical variations concerning Piriformis muscle (P.M.) and Sciatic nerve (S.N.)

Piriformis muscle in contraction acts as an external rotator of the hip, weak abductor of the thigh and weak flexor of the hip, providing in the same time postural stability during standing and ambulation.

Since the pain is caused by the irritation of the sciatic nerve, diagnosis of the piriformis syndrome must take into account several causes for this type of low back pain, such as: lumbosacral radiculopathies, herniated intervertebral disc, degenerative disc disease, spinal stenosis, compression fractures, sacroiliac joint dysfunction, sacroiliitis, ipsilateral shorter leg, arthritis or bursitis of the hip joint, tumors, bowl, bladder or internal gynecological problems.

Boyajian-O'Neil [2] shows that there are two types of piriformis syndrome, a primary piriformis syndrome induced by an anatomic cause, as presented above, and a secondary piriformis syndrome caused by macro or microtrauma, with ischemic mass effect. Macrotrauma of the piriformis is represented by falling on the hip or buttock. Microtraumas are represented by an overuse of the muscle during prolonged gait or run, sitting for a long time in the same position (taxi driver) will lead to muscle inflexibility. Other causes to lead to overuse the piriformis, listed by Campos [4] are, weak gluteal muscles, chronic subluxation of the sacroiliac joints and foot dysfunction.

Usually, piriformis syndrome is a differential and exclusion diagnosis, but a clinical one [8].That's why, the examination of the patient will start with a discussion about the history of the pain and its characteristics, will continue with the observation of the posture and gait of the subject, then the examiner will apply a number of manual tests to elicit the pain due to irritation of the piriformis and finally, if possible from the financial point of view or/and existence in the practice, the examiner will use, diagnostic machines such as CT, MRI, ultrasound and EMG.

A thorough questioning will reveal the symptoms which brought the patient to the ambulatory [2,3]: buttock pain, pain with sitting, pain in standing or lying longer than 15-20 minutes, radiating pain from the sacrum through the buttock down the posterior 
aspect of the thigh, stopping usually above the knee, usually pain reducing with ambulation but increasing with no movement, pain elicited by raising from a seated position or from squatting, with no complete relieve of pain after position changing, sometimes patients will complain about contralateral sacroiliac pain, weakness in ipsilateral lower extremity, numbness in foot etc.

The observation will reveal a limping gait, a classical antalgic gait, due to the sciatic nerve irritation through a contracted piriformis muscle.

In the same time, one may observe a foot dysfunction, more precisely an overpronation of the foot. In case of overpronation, the piriformis will contract to counter the inward movement of the leg during the gait cycle [4]. The advancing leg of the patient, during gait, lands on the outside of the heel, than the foot rolls inward in an overpronated position (usually due to dropped arches).

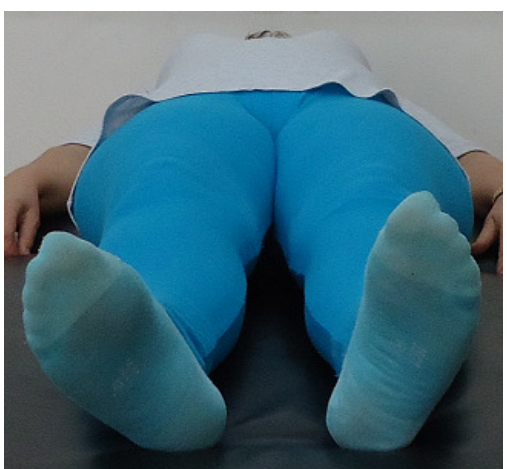

Figure 2. Toe pointing in a greater angle laterally then the one of the healthy opposite leg

In the piriformis syndrome, in a supine and completely relaxed position, due to the contracted piriformis muscle, the ipsilateral lower extremity will rotate outward [5], toe pointing in a greater angle laterally then the one of the healthy opposite leg (Figure 2).

It also might occur a foot drop [2], caused by the compression of the sciatic nerve by the piriformis, more specific the peroneal branch of it.
There are several manual tests used in the practice, to evaluate piriformis muscle status and sciatic nerve.

Palpation of the buttock will reveal a spindle [6]or sausage [2] shaped formation, which is the contracted piriformis muscle. According to Muscolino [7] the palpation of the piriformis muscle will be performed with the subject into a relaxed prone position, with the knee bent at a $90^{\circ}$ angle. The examiner is positioned on the affected side, with one hand supporting the ankle of the patient, the other hand placed lateral to the sacrum, half way between the apex of the sacrum and the postero-superior iliac spine. Piriformis muscle will contract when tight is rotated laterally by moving the foot medially. Rotation will not be to strong, to avoid contraction of the gluteal muscles, and resisted by the hand of the examiner. Once the piriformis has been located, patient will be told to relax for the examiner to be able to palpate and assess the baseline tone of the muscle.

Orthopedic functional tests, used to diagnose the piriformis syndrome, are designed to elicit pain from the piriformis muscle or from the entrapped or irritated sciatic nerve by pressure applied to the muscle, realizing a resisted contraction or stretching of the piriformis muscle.

- The FAIR (Flexion+Adduction+Internal rotation) test is realized with the patient in a lateral recumbent position, with the affected side up [2, 8, 9]. The examiner will flex the patient's hip to an angle of $60^{\circ}$ and the knee to an angle between $60^{\circ}$ and $90^{\circ}$. 


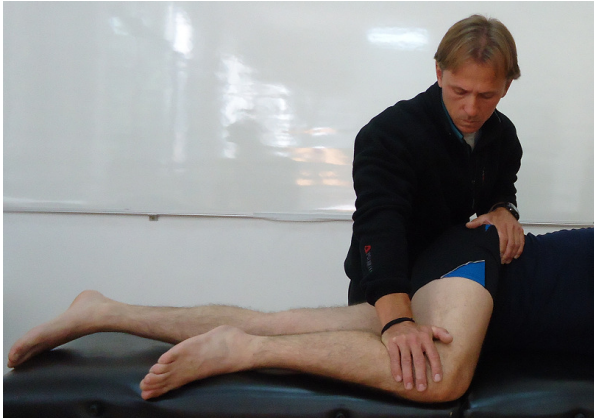

Figure 3. FAIR Test

One hand of the examiner stabilizes the hip of the patient and the other hand rotates and adducts the hip by applying a downward pressure to the knee. The FAIR test is considered positive if the patient reports a pain profound in the middle of the buttock (Figure 3).

- Beatty maneuver $[8,9]$ is realized with the patient in a side-lying position with the affected side up. Unaffected lower limb will keep hip and knee extended while hip and knee of the affected side will be bent both at an angle of $90^{\circ}$, with the knee resting on the table. Patient will be asked to lift the knee of the affected side a few inches from the table and maintain the position. This active abduction will reproduce the pain deep in the buttock if the sciatic nerve is compressed by the piriformis muscle (Figure 4a).

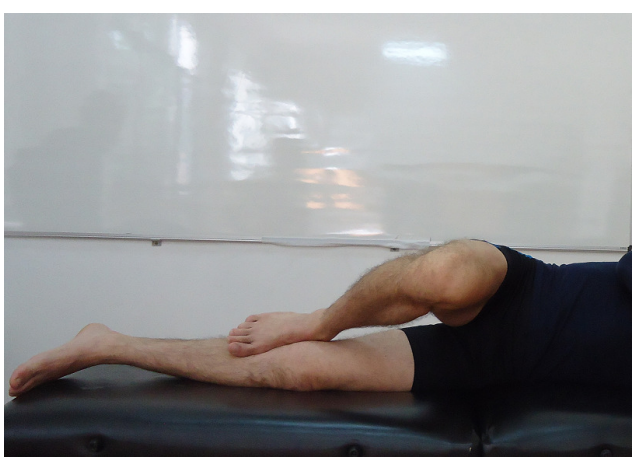

Figure 4a. Beatty maneuver

- Modified Beatty maneuver [8,9] is when the examiner exerts a slight resistance to the abduction with a hand placed on the knee of the patient. The maneuver is positive when the pain is reported in the buttock and not in the lumbar spine, while the patient actively abducts the leg (Figure 4b).

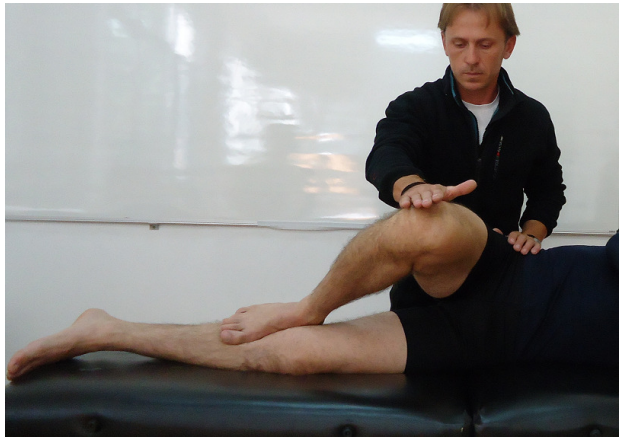

Figure 4b. Modified Beatty maneuver

- Pace test $[8,10]$ will demonstrate alongside the deep buttock pain, weakness on resisted abduction and external rotation of the tight on the affected side. It demonstrates not only the sciatic pain due to a bulky overstressed piriformis but also a loss of function of the muscle. Patient in a seated on the bedside with both tights adducted in a normal resting position will be asked to push apart the hands, of the examiner, placed on the lateral aspects of the knees. This abduction movement will induce deep buttock pain and the examiner will observe faltering and weakness on the same side (Figure 5a). Cummings [8] points out that unfortunately this test is not always positive in piriformis syndrome.

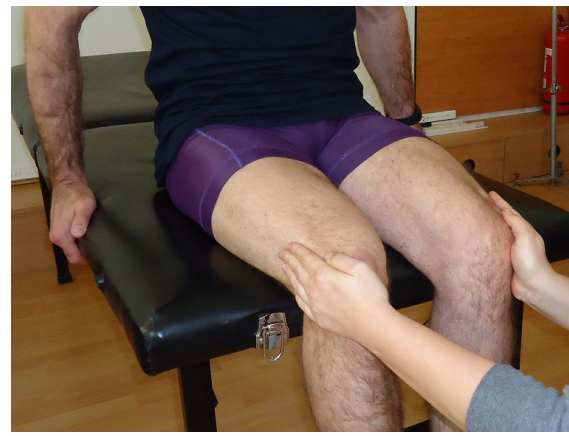

Figure 5a. Pace Test

Since the piriformis muscle acts as a hip (external) rotator when the hip is in extension and a hip abductor when the hip is in flexion, both actions should be tested. 
- The modified Pace test [11] will assess the piriformis muscle as a rotator. The patient in a supine relaxed position with the legs hanging off the table at the knees will be asked to push his legs medially against the resistance provided by the examiner's hands. This movement will produce pain in the deep buttock if there is a piriformis syndrome (Figure 5b).

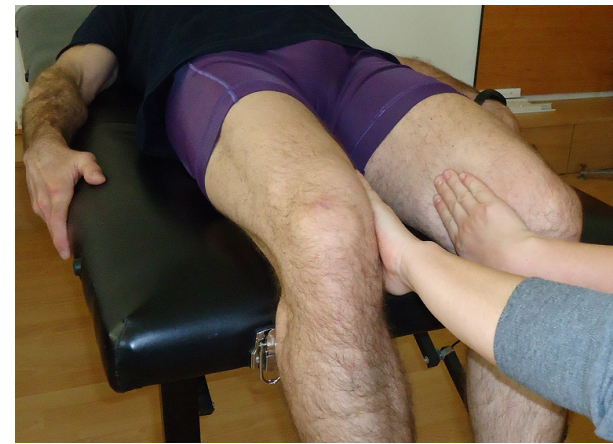

Figure 5b. Modified Pace Test

- The Freiberg test [8, 9, 12] consists in a passive internal rotation of the leg with the hip in extension. Initially Freiberg conceived the test to evaluate the limitations of movement secondary to spastic contraction of the piriformis. The test stretches in the same time the other external rotators of the leg, namely the gemelli, obturator internus and the quadratus femoris. The test is to be conducted with the patient in a prone position with the knee of the painful site flexed to an angle of $90^{\circ}$. The examiner will place one hand under the flexed knee and the other on the heel of the same leg and will induce an internal rotation of the tight by pushing laterally the heel. This movement stretches the piriformis muscle and elicits the pain in the sciatic notch area (Figure 6).

- Bragard test $[5,13,14]$ is used to determine whether the source of lower back pain is nervous or muscular. The patient is in a passive supine position. The examiner, supporting with one hand the ankle, raises the leg of the patient in a straight position to the point of pain, then lowers it $5^{\circ}$ and with the other hand dorsiflexes the ankle. If the pain increses during dorsiflexion the pain is likely of nervous origin. If the pain during dorsiflexion presents no exchange in the intensity then the source is presumed muscular. Usually, if pain appears at an angle of $0^{\circ}-35^{\circ}$ of straight leg flexion, the pain is elicited by a piriformis syndrome or/and a sacro-iliac joint restriction (Figure 7).
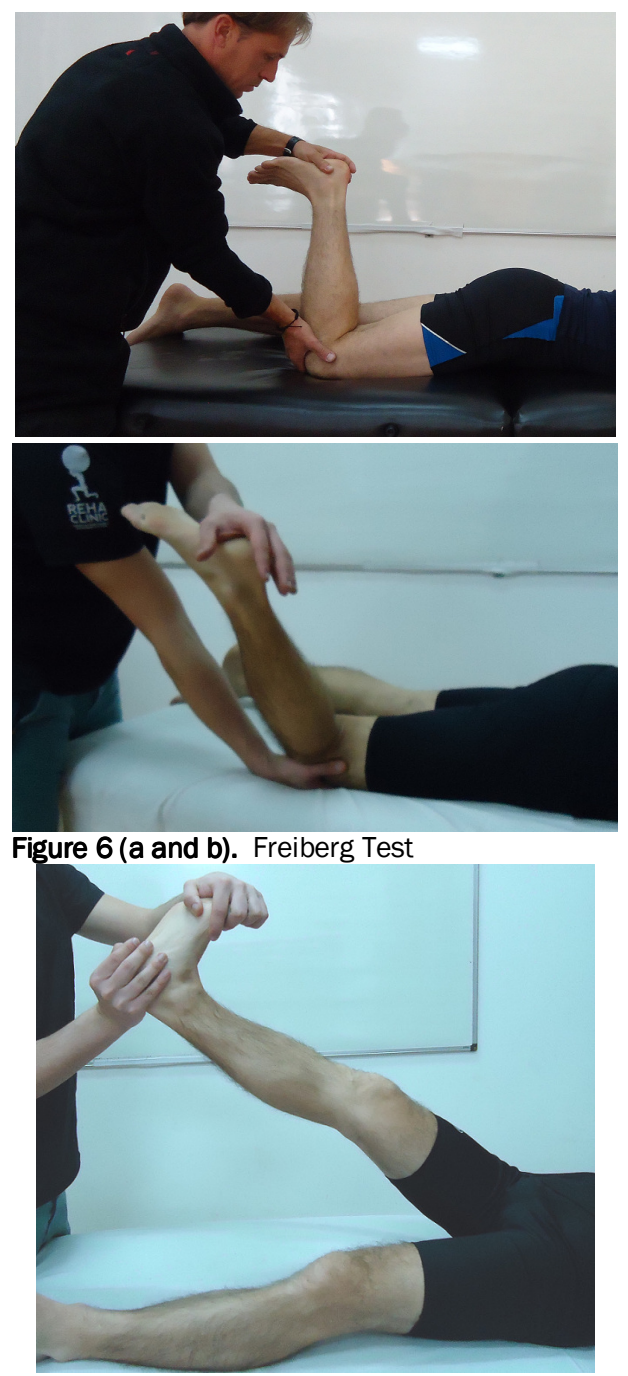

Figure 7. Bragard Test

- Straight leg raise test [8,13 ]is used to determine the level of a lumbar radicular pain. With the patient in a supine relaxed position, both legs extended on the couch, the examiner raises the leg 
on the side to be examined by supporting it with one hand at the ankle, until pain is reported. Usually if pain, if pain appears at an angle of $0^{\circ}$ $35^{\circ}$ of straight leg flexion, the pain is elicited by a piriformis syndrome or/and a sacro-iliac joint restriction (Figure 8).

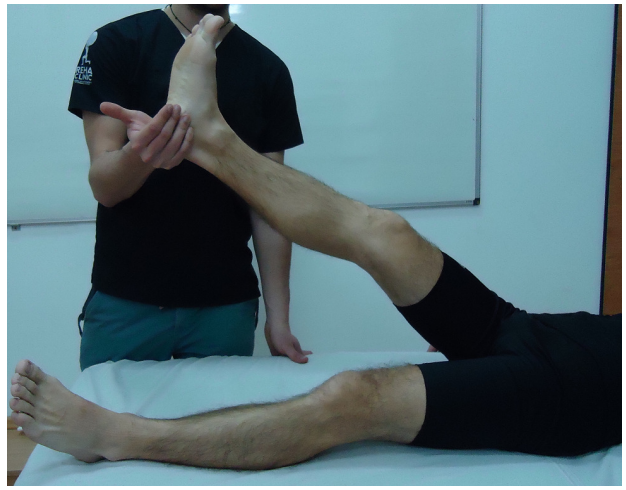

Figure 8. Straight leg Test

- Bonnet test [14] is performed with the patient in a passive supine position. The examiner realizes a straight leg raise on the affected side, with the hip adducted and realizes an internal rotation of the thigh by supporting with one hand the calf and with the other hand stabilizing the knee. The test will be positive if pain or paresthesia are reported, being specific for sciatica and piriformis syndrome (Figure 9).

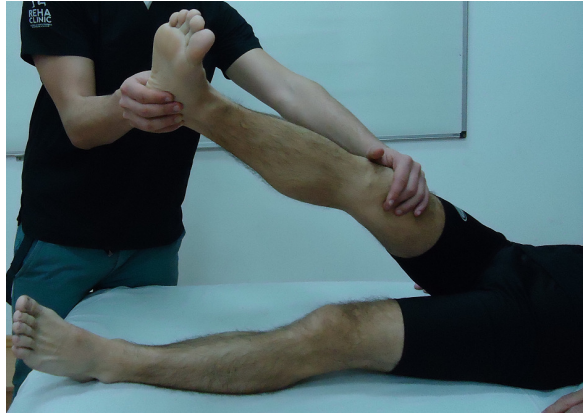

Figure 9. Bonnet Test

- Mirkin test [15] - the examiner exerts a pressure into the buttock where the sciatic nerve crosses the piriformis muscle and asks the patient to bend slowly to the floor. If the movement elicits a deep buttock pain the test is positive (Figure 10).

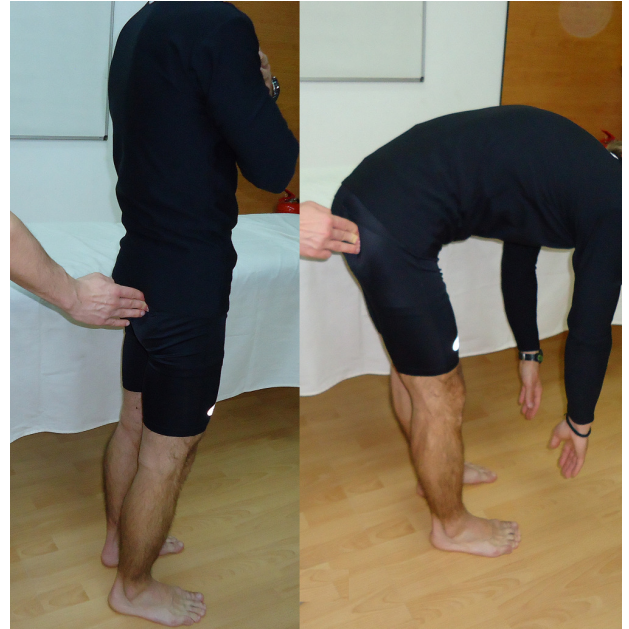

Figure 10. Mirkin Test

- The Piriformis muscle stretch [8] is performed with the subject on a side-lying position, with the affected side up. With the hip flexed at 90 degrees, the examiner with one hand on the knee adducts the flexed hip while retracting the ilium with the other hand. This movement will produce an almost isolated stretch of the piriformis muscle (Figure 11).

To complete the evaluation and be able to exclude radicular, tumoral or other reffered pains from gastrointestinal or pelvic causes from sciatica, one may use Computed tomography (CT), Magnetic resonance imaging (MRI), Electromyography (EMG) and Neurography $[2,8]$.

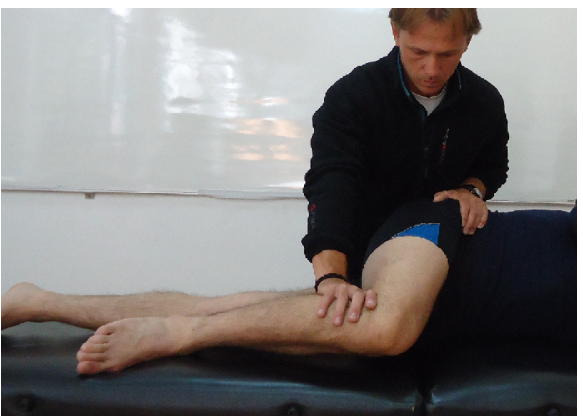

Figure 11. Piriformis muscle stretch 


\section{Conclusions}

Sciatica produced by an overstressed and bulky piriformis muscle may be diagnosed through observation of the position and way to move of the patient and through simple functional tests. The tests presented in the present paper reproduce the pain reported by the patient through movements which stretch or over contract the piriformis muscle. The most popular tests from the above are the FAIR test, Beatty maneuver, Freiberg test and the Pace test.

In conclusion, even if a practitioner does not have the opportunity to use CT, MRI or EMG, by using the functional orthopedic tests described in the present paper should be able to diagnose a sciatica due to piriformis syndrome.

\section{References}

1. Hoag M. H. (2005) Piriformis syndrome, The Gale Group Inc. Gale Encyclopedia of Neurological Disorders;

2. Boyajian-O'neil L..A., McClain, R.L., Coleman, M.K., THOMAS, P.P. (2008), Diagnosis and management of piriformis syndrome: an osteopathic approach, J.Am.Osteopath Assoc. 2008 Nov; 108(11): 657-64;

3. Hallin R.P. (1983) Sciatic pain and the piriformis muscle, Postgrad Med. 1983; 74: 69-72;

4. Campos N. (2010) What causes piriformis syndrome, September 2010, http://www.drnickcampos.com/healthnewsletter/PiriformisSyndrome.html;

5. Fuhr Arlan D.C.(2005) Piriformis syndrome: Assesment \& Correction of Affected Structures,

http://www.theamericanchiropractor.com/articlestechniques/5657-piriformis-syndrome-assesment-acorrection-of-affected-structures.html;

6. Benzon T.H., Katz J.A., Benzon H.A., Iqbal M.S. (2003) Piriformis syndrome - Anatomic considerations, a new injection technique, and a review of the literature, Anesthesiology 2003; 98: 1442-8;
7. Muscolino J. (2009) The Muscle and Bone Palpation Manual - with Trigger Points, refferal Patterns and Stretching, Mosby - Elsevier;

8. Cummings M. (2000) Piriformis Syndrome, Accupuncture in Medicine, Dec. 2000; vol.18: 108-121;

9. Kirschner J.S., Foye P.M., Cole J.L. (2009) Piriformis syndrome, diagnosis and treatment, Muscle Nerve. 2009; 40(1):10-18;

10. Pace J.B., Nagle D. (1976) Piriformis syndrome, West.J.Med, Jun; 124:435-439;

11. Hammer W.(1991) Piriformis syndrome: Part I, Dynamic Chiropractic, June 21, Vol. 09, Issue 13;

12. Freiberg A.H., Vincle T.H. (1933) Sciatica and the sacro-iliac joint, J.Bone Joint Surg.; 16:1;

13. $* * *(2012)$ Medical Dictionary for the Health Professions and Nursing (๑) Farlex 2012;

14. Miller K.J. (2007) Physical assesment of lower extremity radiculopathy and sciatica, Journal of Chiropractic Medicine; 6:75-82;

15. Das Prodyut (2013) Pirformis muscle syndrome, http://www.physiotherapy-treatment.com/piriformis-musclesyndrome.html 